\title{
Bioavailability of metals in some selected plants grown on an abandoned coal mine overburden using energy dispersive $X$-ray fluorescence technique
}

\author{
E. OKORIE ${ }^{1 *}$ and J.N. EGILA ${ }^{2}$ \\ ${ }^{l}$ Department of Science Laboratory Technology, School of Technology, Federal Polytechnic Idah, \\ P.M.B. 1037 Idah, Kogi State, Nigeria. \\ ${ }^{2}$ Department of Chemistry, Faculty of Natural Sciences, University of Jos, P.M.B. 2084 Jos, \\ Plateau State, Nigeria. \\ ${ }^{*}$ Corresponding author; E-mail: e.okorieslt@yahoo.com; Tel: +2348059430990
}

\begin{abstract}
This study focuses on the bioavailability of some metals in Mangifera indica, Parkia biglobosa, Proposis africanus, Anacardium occidentale and Manihot esculenta plants grown on an abandoned coal mine overburden. The analytical technique used in this study is energy dispersive $\mathrm{x}$-ray fluorescence spectrometry. The results indicate that the plants have the tendency to bioaccumulate the metals studied in this order: Proposis africanus $>$ Anacardium occidentale $>$ Manihot esculenta $>$ Parkia biglobosa $>$ Mangifera indica . The various concentrations of the observed metals in the plants grown in overburden soil were considerably lower than those observed from the control soil. This however was attributed to the increase in the sorption of metals with increasing $\mathrm{pH}$. The concentration of metals in the overburden plants ranged from $0.60-18.00$ $\mathrm{mg} / \mathrm{kg}(\mathrm{Ti}) ; 1.03-1.78 \mathrm{mg} / \mathrm{kg}(\mathrm{Cr}) ; 5.81-67.27 \mathrm{mg} / \mathrm{kg}(\mathrm{Mn}) ; 6.03-51.17 \mathrm{mg} / \mathrm{kg}(\mathrm{Fe}) ; 0.30-2.91 \mathrm{mg} / \mathrm{kg}$ $(\mathrm{Ni}) ; 2.32-15.66 \mathrm{mg} / \mathrm{kg}(\mathrm{Cu}) ; 0.54-6.15 \mathrm{mg} / \mathrm{kg}(\mathrm{Re}) ; 3.50-8.90 \mathrm{mg} / \mathrm{kg}(\mathrm{Au}) ; 0.16-3.69 \mathrm{mg} / \mathrm{kg}(\mathrm{Zn}) ; 0.69$ $-3.55 \mathrm{mg} / \mathrm{kg}(\mathrm{Sr}) ; 14.04-111.57 \mathrm{mg} / \mathrm{kg}(\mathrm{Ru}) ; 0.67-2.84 \mathrm{mg} / \mathrm{kg}(\mathrm{Y})$ and $1.79-15.22 \mathrm{mg} / \mathrm{kg}(\mathrm{Ba})$. For the control plants $50 \mathrm{Km}$ from mine site overburden, the observed concentration ranged from $2.34-14.40 \mathrm{mg} / \mathrm{Kg}$ (Ti); 1.16 - $2.56 \mathrm{mg} / \mathrm{kg}(\mathrm{Cr}) ; 4.19-54.95 \mathrm{mg} / \mathrm{kg}(\mathrm{Mn}) ; 15.05-101.50 \mathrm{mg} / \mathrm{kg}(\mathrm{Fe}) ; 0.79-4.56 \mathrm{mg} / \mathrm{kg}(\mathrm{Ni}) ;$ $5.99-24.45 \mathrm{mg} / \mathrm{kg}(\mathrm{Cu}) ; 2.77$ - $10.77 \mathrm{mg} / \mathrm{kg}(\mathrm{Re}) ; 4.70-12.00 \mathrm{mg} / \mathrm{kg}(\mathrm{Au}) ; 0.08-49.08 \mathrm{mg} / \mathrm{kg}(\mathrm{Zn}) ; 1.10-$ $5.08 \mathrm{mg} / \mathrm{kg}(\mathrm{Sr}) ; 41.37-210.24 \mathrm{mg} / \mathrm{kg}(\mathrm{Ru}) ; 1.18-4.10 \mathrm{mg} / \mathrm{kg}(\mathrm{Y})$ and $0.29-7.52 \mathrm{mg} / \mathrm{kg}$ (Ba). The values obtained are far above World Health Organization tolerable daily intake and are attributed to the nature of the soil in the mineral rich coal basin.
\end{abstract}

() 2014 International Formulae Group. All rights reserved.

Keywords: Biosorption, bioremediation, absorption, heavy metals, overburden.

\section{INTRODUCTION}

Plants have the natural ability to absorb metals. Some of these metals are essential mineral nutrients such as $\mathrm{Cu}, \mathrm{Co}, \mathrm{Fe}, \mathrm{Mo}, \mathrm{Mn}$, $\mathrm{Ni}$ and $\mathrm{Zn}$, others like $\mathrm{Cd}$ has no known physiological activity. This inherent ability of plants to take up metals makes them useful in phytoremediation. This can only be achieved if the following factors are taken into consideration: the extent of soil contamination; metal availability for uptake into roots, and plant ability to intercept, absorb, and accumulate metals in shoots (Ernst, 1996).

Several studies have shown that soil microorganisms possess mechanisms capable 
of altering environmental mobility of metal contaminants with subsequent effects on the potential for root uptake (Lasat, 2002). In addition, soil microorganisms have been shown to exude organic compounds which stimulate bioavailability and facilitate root absorption of a variety of metal ions including $\mathrm{Fe}^{2+}$ (Crowley et al., 1991; Bural et al., 2000), $\mathrm{Mn}^{2+}$ and possibly $\mathrm{Cd}^{2+}$ (Salt et al., 1995). Microbes have been shown to catalyse redox transformations leading to changes in soil metal bioavailability and potential for phytoextraction. In addition, the exudation of organic compounds from roots has been shown to affect root absorption of certain metals. In soil, metals exist as a variety of chemical species in a dynamic equilibrium governed by soil physical, chemical, and biological properties (Chaney, 1988). The kinetics of this interaction, which ultimately dictates the extent of metal bioavailability, is poorly understood. Only a fraction of soil metal is readily available (bioavailable) for plant uptake. The majority of soil metals are commonly found as insoluble compounds unavailable for transport into roots. With the exception of mercury, metal uptake into roots occurs from aqueous phase. In soil, some metals such as $\mathrm{Zn}$ and $\mathrm{Cd}$ occur primarily as soluble or exchangeable, readily bioavailable form. Others such as $\mathrm{Pb}$ occur as insoluble precipitates (phosphates, carbonates, and hydroxy-oxides) which are largely unavailable for plant uptake (Pitchell et al., 1999). Binding and immobilization within the soil matrix can significantly restrict the potential for metal phytoextraction (Thangavel and Subbhuraam, 2004).

Plants possess highly specialized mechanisms to stimulate metal bioavailability in the rhizosphere, and to enhance uptake in roots (Romheld and Marschner, 1986). Transport across root cellular membrane is an important process which initiates metal absorption into plant tissues. The electrical charge prevents metal ions from diffusing freely across the lipophilic cellular membranes into the cytosol (Hart et al., 1998). Increased mobility of metals can be stimulated by plant roots which include changes in $\mathrm{pH}$, reducing capacity and the amount and composition of exudates (Bernal and McGrath, 1994) and use of chelating agents (Violante et al., 2010). Previous work have shown that some trace metals like $\mathrm{Ni}$ is a component of a number of enzymes, including glyoxalates, reductase, ureases, and a few superoxide dismulases and hydrogenases (Kupper and Kroneck, 2007). Some of the objectionable increases in the concentration of some of these heavy metals may be attributed to mineral compositions and soil amendments (Begonia et al., 2005).

The aim of this work is to investigate the bioavailable heavy metals in some plants grown on a coal mine site overburden using energy dispersive $\mathrm{x}$-ray fluorescence spectrometric technique.

\section{MATERIALS AND METHODS}

The equipment used in this study is MiniPal ED-XRF (Panalytical B.V. MiniPal 4 model Lelyweg, Netherlands) and the chemical used is cellulose acetate binder.

\section{Sample preparation}

The plant samples were obtained from an overburden close to Panel 10B coal mine pit at Achokpa, Kogi State, Nigeria (Figures 1 and 2). The parts of the plants used are the stem and leaf. The plant samples used for this bioavailability study are Mangifera indica $L$, Manihot esculenta, Anacardium occidentale, Parkia biglobosa and Proposis africanus. The samples were obtained and dried at room temperature. They were then pulverized to a particle size of $<5 \mu$ using a mortar and pestle and stored in a polythene bag. In the absence of further treatment, $20 \mathrm{~g}$ of the samples were individually and intimately mixed with a binder in the ratio of 5:1 cellulose acetate binder and pelletised at a pressure of 10-15 tons/inch ${ }^{2}$ in a pelletizing machine (Robert, 1992). The pelletized samples were stored in desiccators for analysis.

\section{Analytical processes}

$\mathrm{X}$-ray fluorescence spectrometry is widely used in the analysis of solid, liquid and gaseous petroleum samples. Simple sample 
preparation, high accuracy and precision and good detection limits are the principle reasons for this choice and make it an excellent technique for production control. The measurement condition used for the analysis of the elements in the samples is the $K \alpha$ fluorescent lines for each element were used to set up the calibrations. Calibrating many identical systems for the same application is time consuming. The integrated re-calibration package in the MiniPal software makes it possible to calibrate only one system and to transfer this calibration to the other systems without re-measuring all standards again.

\section{Preparation of standards}

A set of toxic heavy elements and nonmetals standards from BCS/CRM and BCS/Euro standards was used to set up the calibrations. The trace element composition and homogeneity of these standards were assessed using ICP-MS and NAA as independent and reliable analytical methods.

\section{Instrumentation}

The measurements were performed using a Panalytical B.V. MiniPal 4 model
EDXRF spectrometer Lelyweg, Netherlands. It runs on a new version of software for MiniPal spectrometers that adds considerable flexibility for fast elemental analysis across the full spectrum of the entire periodic table. The MiniPal 4 software includes a variety of features that simplify applications set-up and data handling, such as re-calibration, spectra comparison, robust application defaults and extended calibration options. This instrument is equipped with a rhodium anode tube, 5 tube filters, a helium purge facility, high-resolution lithium -silicon drift detector and a 12position removable sample changer with sample spinner. The tube setting is software controlled with a maximum power of $9 \mathrm{~W}$. The measuring time for each sample is 60 seconds in an air medium.

\section{Voltage settings}

The voltage settings for the analysis of various metals are in the following range: $\mathrm{Na} \rightarrow \mathrm{Cl}$ (4-12 V). The optimised voltage used is $8 \mathrm{~V} . \mathrm{K} \rightarrow \mathrm{V}(12-20 \mathrm{~V})$ has an optimised voltage of $18 \mathrm{~V} . \mathrm{Cr} \rightarrow \mathrm{Co}(20-25 \mathrm{~V})$ with an optimsed voltage of $25 \mathrm{~V}$ and $\mathrm{Ni} \rightarrow \mathrm{Ag}(25-30)$ with an optimized voltage of $28 \mathrm{~V}$.

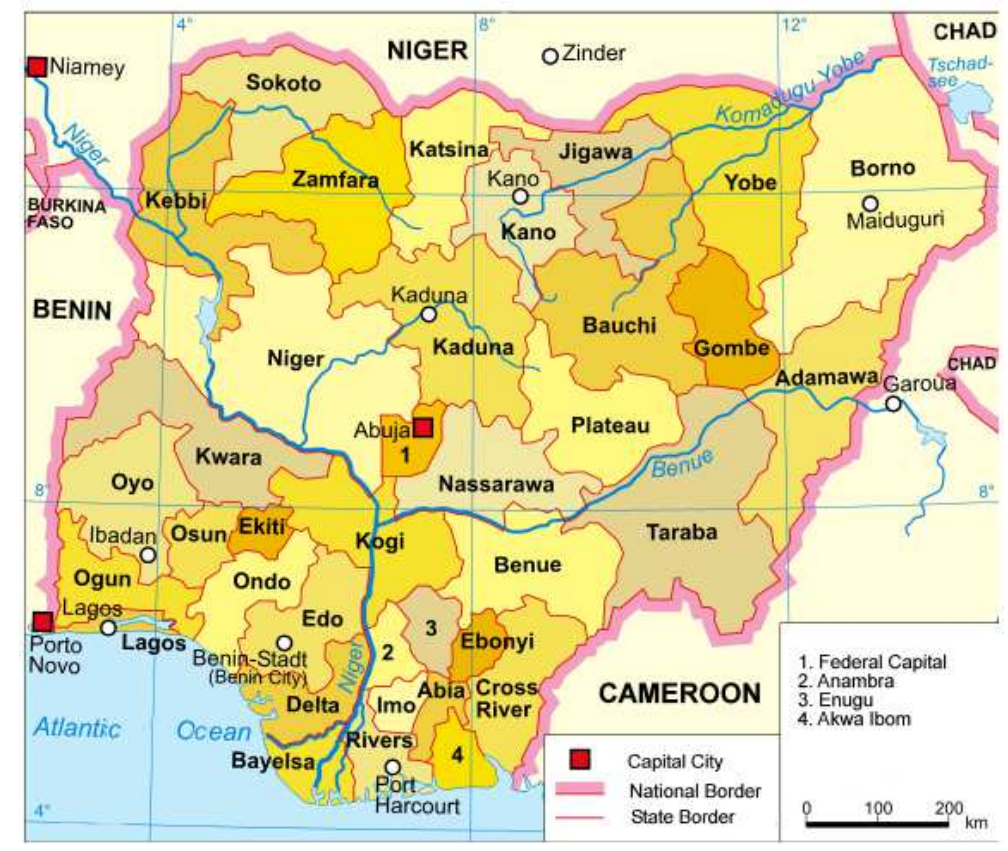

Figure 1: Map of Nigeria showing Kogi State. 


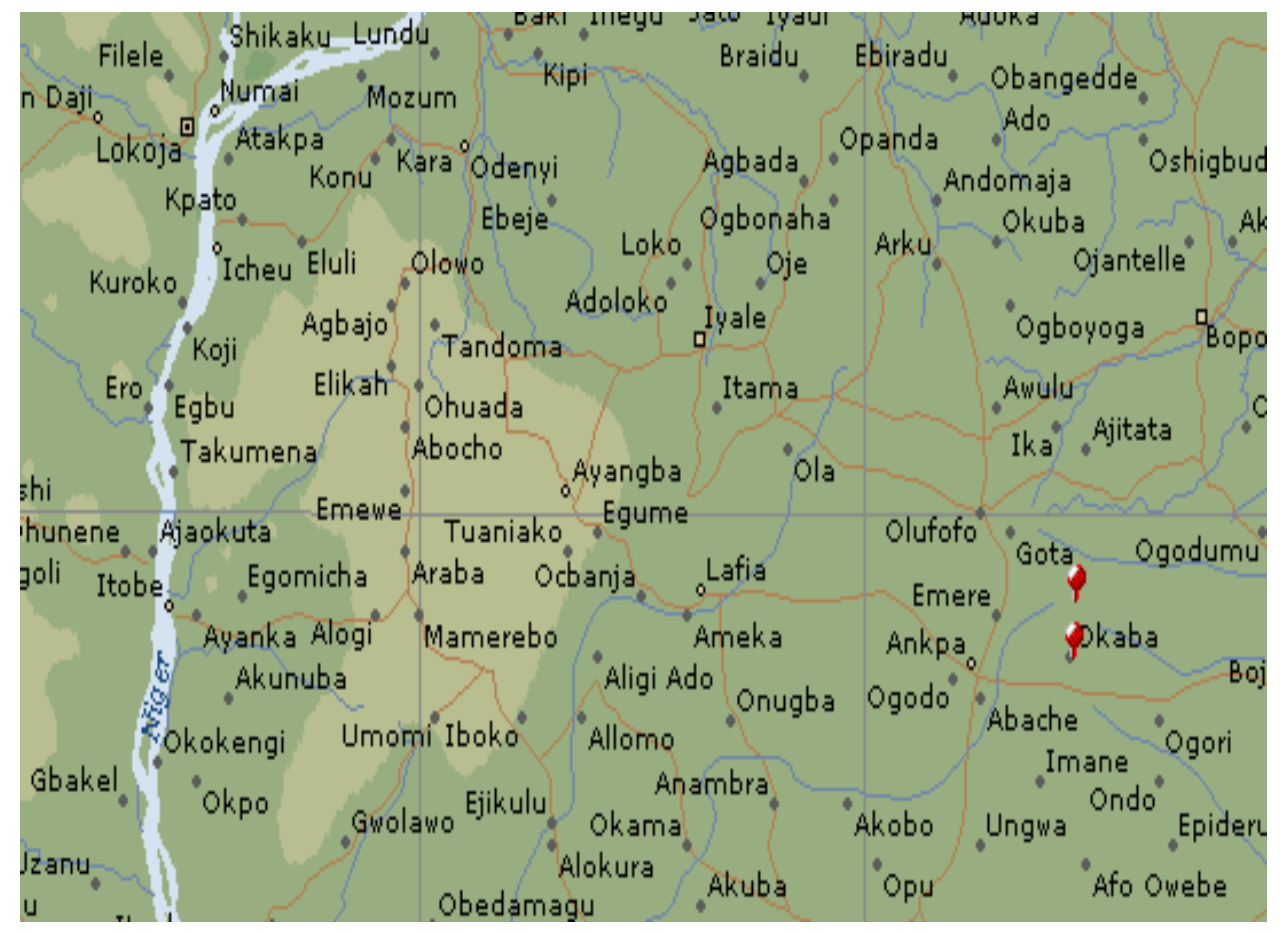

Figure 2: Map of Kogi State, Nigeria, showing Okaba (study area).

\section{RESULTS}

The results of the ED-XRF analysis of Mangifera indica L, Manihot esculenta, Anacardium occidentale, Parkia biglobosa and Proposis africanus samples from mine overburden are presented in Table 1 while that from control plant $50 \mathrm{~km}$ from mine overburden are presented in Table 2 .

The bioavailability of metals in the plants studied; Mangifera indica L (mango), Manihot esculenta (cassava), Anacardium occidentale (cashew), Parkia biglobosa (ugba) and Proposis africanus (okpeyi) indicates elevated levels in some of the metals on the plants. Titanium levels in mango stem is $7.80 \mathrm{mg} / \mathrm{kg}$ while a concentration of 0.60 $\mathrm{mg} / \mathrm{kg}$ was recorded at the leaf. The observed level at the control mango stem is $4.32 \mathrm{mg} / \mathrm{kg}$ and $2.34 \mathrm{mg} / \mathrm{kg}$ at the leaf. The concentration observed at the ugba stem and leaves are 4.98 $\mathrm{mg} / \mathrm{kg}$ and $4.14 \mathrm{mg} / \mathrm{kg}$ respectively, while at the control ugba plant, the observed concentrations at the stem and leaf are 3.24 $\mathrm{mg} / \mathrm{kg}$ and $6.00 \mathrm{mg} / \mathrm{kg}$ respectively. Okpeyi stem and leaf in the mine overburden are 2.52 $\mathrm{mg} / \mathrm{kg}$ and $4.92 \mathrm{mg} / \mathrm{kg}$ respectively while in those grown in control soil are $14.40 \mathrm{mg} / \mathrm{kg}$ and $7.20 \mathrm{mg} / \mathrm{kg}$ respectively. Cashew stem and leaf had elevated levels of $\mathrm{Ti}$ in the mine overburden with values of $18.00 \mathrm{mg} / \mathrm{kg}$ and $5.22 \mathrm{mg} / \mathrm{kg}$ respectively, while those grown on the control soil indicated concentrations of $4.56 \mathrm{mg} / \mathrm{kg}$ and $3.24 \mathrm{mg} / \mathrm{kg}$ respectively. The concentration of $\mathrm{Ti}$ in cassava stem and leaf are $1.86 \mathrm{mg} / \mathrm{kg}$ and $3.90 \mathrm{mg} / \mathrm{kg}$ respectively, while that of cassava grown on control soil are $5.88 \mathrm{mg} / \mathrm{kg}$ and $2.46 \mathrm{mg} / \mathrm{kg}$ respectively.

Chromium was not detected in mango and ugba plants but was observed in cashew stem and leaf with concentrations of 1.51 $\mathrm{mg} / \mathrm{kg}$ and $1.78 \mathrm{mg} / \mathrm{kg}$ respectively, while in cassava leaf and okpeyi stem, the recorded concentrations are $1.03 \mathrm{mg} / \mathrm{kg}$ and $1.64 \mathrm{mg} / \mathrm{kg}$ respectively. In contrast to the above result, $\mathrm{Cr}$ 
was detected in the control plants with a range of $1.16-2.53 \mathrm{mg} / \mathrm{kg}$. Mango and cassava leaves showed no detectable concentrations of Cr. Cassava stem and leaf in the overburden soil recorded concentrations of $\mathrm{Mn}$ as 10.85 $\mathrm{mg} / \mathrm{kg}$ and $10.08 \mathrm{mg} / \mathrm{kg}$ respectively, while the values obtained from control soil are 5.04 $\mathrm{mg} / \mathrm{kg}$ (stem) and $4.65 \mathrm{mg} / \mathrm{kg}$ (leaf). The concentrations of Mn observed for cashew in overburden are $6.67 \mathrm{mg} / \mathrm{kg}$ (stem) and 16.28 $\mathrm{mg} / \mathrm{kg}$ (leaf), while that of control soil are $4.19 \mathrm{mg} / \mathrm{kg}$ (stem) and $14.73 \mathrm{mg} / \mathrm{kg}$ (leaf). Ugba plant in overburden has $\mathrm{Mn}$ as 5.81 $\mathrm{mg} / \mathrm{kg}$ (stem) and $31.62 \mathrm{mg} / \mathrm{kg}$ (leaf); that of control soil are $5.43 \mathrm{mg} / \mathrm{kg}$ (stem) and 16.90 $\mathrm{mg} / \mathrm{kg}$ (leaf). The above results indicate that Mn concentration in the overburden is more than that of control soil.

Iron is the second most abundant metal in the earth's crust. Therefore the results obtained for $\mathrm{Fe}$ in the analysis of plant samples grown on mine overburden and control soil are quite high. The observed ranges for plants grown on mine overburden are $6.03-51.17 \mathrm{mg} / \mathrm{kg}$, while that for control soil $15.05-101.50 \mathrm{mg} / \mathrm{kg}$. Copper absorption by plants grown on mine overburden ranged from 2.32 - $15.66 \mathrm{mg} / \mathrm{kg}$. Okpeyi plant has the highest concentration with values of 13.50 $\mathrm{mg} / \mathrm{kg}$ (stem), and $15.66 \mathrm{mg} / \mathrm{kg}$ (leaf), followed by cashew plant with concentrations of $8.79 \mathrm{mg} / \mathrm{kg}$ (stem) and $14.70 \mathrm{mg} / \mathrm{kg}$ (leaf). The observed concentration from control soil plants ranged from 5.99 - $24.45 \mathrm{mg} / \mathrm{kg}$. Okpeyi plant has the highest concentration with values of $24.42 \mathrm{mg} / \mathrm{kg}$ (stem), and 21.81 $\mathrm{mg} / \mathrm{kg}$ (leaf) followed by cashew plant $15.58 \mathrm{mg} / \mathrm{kg}$ (stem) and $17.74 \mathrm{mg} / \mathrm{kg}$ (leaf).

Rhenium was detected in plant samples from both soils. Observed levels of $\mathrm{Re}$ in plants from overburden soil ranged from 0.54 $-6.31 \mathrm{mg} / \mathrm{kg}$. Okpeyi plant has a slightly high concentration of $5.69 \mathrm{mg} / \mathrm{kg}$ (stem) and 6.15 $\mathrm{mg} / \mathrm{kg}$ (leaf), followed by cashew with concentrations of $3.08 \mathrm{mg} / \mathrm{kg}$ (stem) and 6.31 $\mathrm{mg} / \mathrm{kg}$ (leaf). In the control plant samples, the observed concentration of $\mathrm{Re}$ ranged from $2.77-10.77 \mathrm{mg} / \mathrm{kg}$. Accordingly, Okpeyi has a concentration of $10.77 \mathrm{mg} / \mathrm{kg}$ (stem) and $8.46 \mathrm{mg} / \mathrm{kg}$ (leaf), while cashew plant has a concentration $5.54 \mathrm{mg} / \mathrm{kg}$ (stem) and 6.77 $\mathrm{mg} / \mathrm{kg}$ (leaf). This trend is closely applied to the biosorption of $\mathrm{Au}$ in plants from the soil samples studied. In overburden soil plants, Au ranged from $3.50-8.90 \mathrm{mg} / \mathrm{kg}$, while in the control soil it ranged from $4.70-12.00$ $\mathrm{mg} / \mathrm{kg}$. However, Okpeyi plant showed a concentration of $7.10 \mathrm{mg} / \mathrm{kg}$ (stem) and 8.90 $\mathrm{mg} / \mathrm{kg}$ (leaf), while cashew plant has concentrations of $0.0 \mathrm{mg} / \mathrm{kg}$ (stem) and 7.80 $\mathrm{mg} / \mathrm{kg}$ (leaf). In the control plants, detected concentrations of Au in Okpeyi are $0.0 \mathrm{mg} / \mathrm{kg}$ (stem) and $12.00 \mathrm{mg} / \mathrm{kg}$ (leaf), while for cashew, the observed concentration of $\mathrm{Au}$ are $8.50 \mathrm{mg} / \mathrm{kg}$ (stem) and $9.80 \mathrm{mg} / \mathrm{kg}$ (leaf).

Zinc sorption in plants from the soil samples is relatively low except cassava stem with a detected concentration of $49.08 \mathrm{mg} / \mathrm{kg}$ from control soil. The range of $\mathrm{Zn}$ in overburden soil is $0.16-3.69 \mathrm{mg} / \mathrm{kg}$, while for control soil, the concentration of $\mathrm{Zn}$ ranged from $0.08-49.08 \mathrm{mg} / \mathrm{kg}$. Ruthenium had the highest concentration in all the plants analysed. For plants grown on mine overburden soil, $\mathrm{Ru}$ biosorption ranged from $14.04-111.57 \mathrm{mg} / \mathrm{kg}$. Okpeyi has the highest biosorption concentration with values of 98.67 $\mathrm{mg} / \mathrm{kg}$ (stem) and $111.57 \mathrm{mg} / \mathrm{kg}$ (leaf). This was followed by cassava with values of 58.14 $\mathrm{mg} / \mathrm{kg}$ (stem) and $34.08 \mathrm{mg} / \mathrm{kg}$ (leaf). Ru was not detected in cashew plant. Considerably high concentrations were observed in ugba leaf $(51.16 \mathrm{mg} / \mathrm{kg})$ and stem $(39.32 \mathrm{mg} / \mathrm{kg})$; mango stem $(52.30 \mathrm{mg} / \mathrm{kg})$ and leaf $(14.04$ $\mathrm{mg} / \mathrm{kg}$ ). 
Table 1: Results of ED-XRF analysis of some selected plant samples grown on open pit mine site overburden (mg/kg).

\begin{tabular}{|c|c|c|c|c|c|c|c|c|c|c|c|c|c|}
\hline & $\mathbf{T i}$ & $\mathrm{Cr}$ & Mn & $\mathbf{F e}$ & $\mathbf{N i}$ & $\mathbf{C u}$ & $\mathbf{R e}$ & Au & Zn & $\mathrm{Sr}$ & $\mathbf{R u}$ & $\mathbf{Y}$ & $\mathbf{B a}$ \\
\hline Mango stem & 7.80 & ND & 27.82 & 23.80 & 0.79 & 7.67 & ND & ND & ND & 3.30 & 52.30 & 1.81 & 8.50 \\
\hline Mango leaf & 0.60 & ND & 67.27 & 6.03 & 0.30 & 2.32 & 0.54 & ND & 0.16 & 0.69 & 14.04 & 0.67 & 2.69 \\
\hline Ugba stem & 4.98 & ND & 5.81 & 30.38 & 2.12 & 8.87 & 3.08 & ND & 0.72 & 2.03 & 39.32 & 1.34 & 7.07 \\
\hline Ugba leaf & 4.14 & ND & 31.62 & 29.12 & 1.49 & 8.79 & 3.85 & 4.30 & 0.80 & 3.55 & 51.16 & 1.97 & 15.22 \\
\hline Okpeyi stem & 2.52 & 1.64 & 7.05 & 18.69 & 2.20 & 13.50 & 5.69 & 7.10 & 3.69 & 2.28 & 98.67 & ND & ND \\
\hline Okpeyi leaf & 4.92 & ND & 44.18 & 44.45 & 2.91 & 15.66 & 6.15 & 8.90 & 2.49 & ND & 111.57 & ND & ND \\
\hline Cashew stem & 18.00 & 1.51 & 6.67 & 51.17 & 1.57 & 8.79 & 3.08 & ND & 0.48 & 2.12 & ND & ND & 3.58 \\
\hline Cashew leaf & 5.22 & 1.78 & 16.28 & 35.00 & 2.67 & 14.70 & 6.31 & 7.80 & 0.80 & ND & ND & 2.84 & ND \\
\hline Cassava stem & 1.86 & ND & 10.85 & 13.72 & 1.89 & 10.63 & 4.92 & 5.00 & 1.52 & 2.79 & 58.14 & ND & 4.48 \\
\hline Cassava leaf & 3.90 & 1.03 & 10.08 & 34.86 & 1.26 & 7.75 & 3.08 & 3.50 & 1.85 & 1.61 & 34.08 & ND & 1.79 \\
\hline
\end{tabular}

Mangifera indica L. (Mango), Parkia biglobosa (Ugba), Proposis africanus (Okpeyi), Anacardium occidentale (Cashew) and Manihot esculenta (Cassava)

ND: Not Detected.

Table 2: Results of ED-XRF analysis of some selected plant samples grown on control soil - 50Km from open pit mine site (mg/kg).

\begin{tabular}{|c|c|c|c|c|c|c|c|c|c|c|c|c|c|}
\hline & $\mathbf{T i}$ & $\mathrm{Cr}$ & Mn & $\mathbf{F e}$ & $\mathrm{Ni}$ & $\mathbf{C u}$ & $\mathbf{R e}$ & Au & $\mathbf{Z n}$ & $\mathbf{S r}$ & Ru & $\mathbf{Y}$ & $\mathbf{B a}$ \\
\hline Mango stem & 4.32 & 1.30 & 6.59 & 25.27 & 1.57 & 8.79 & 4.00 & 4.70 & ND & ND & ND & ND & ND \\
\hline Mango leaf & 2.34 & ND & 23.64 & 15.05 & 1.26 & 7.27 & 3.38 & $\mathrm{ND}$ & 0.40 & 1.44 & 45.24 & $\mathrm{ND}$ & ND \\
\hline Ugba stem & 3.24 & 1.16 & 5.43 & 28.49 & 4.09 & 6.87 & 3.00 & ND & 0.08 & 5.08 & 46.68 & 1.18 & 7.52 \\
\hline Ugba leaf & 6.00 & 1.30 & 16.90 & 53.97 & 1.65 & 8.79 & 3.85 & 6.20 & 2.17 & 1.95 & 71.27 & ND & 4.48 \\
\hline Okpeyi stem & 14.40 & 2.53 & 6.12 & 101.50 & 4.56 & 24.45 & 10.77 & ND & ND & ND & 210.24 & 4.10 & ND \\
\hline Okpeyi leaf & 7.20 & 2.26 & 54.95 & 71.4 & 3.93 & 21.81 & 8.46 & 12.00 & 2.33 & ND & 159.39 & 4.02 & ND \\
\hline Cashew stem & 4.56 & 1.92 & 4.19 & 32.83 & 2.44 & 15.58 & 5.54 & 8.50 & 0.08 & ND & 143.45 & ND & ND \\
\hline Cashew leaf & 3.24 & 2.19 & 14.73 & 24.01 & 2.99 & 17.74 & 6.77 & 9.80 & 0.40 & ND & 121.44 & 2.68 & ND \\
\hline Cassava stem & 5.88 & 1.23 & 5.04 & 26.67 & 1.26 & 7.83 & ND & $\mathrm{ND}$ & 49.08 & 1.52 & 41.37 & ND & 0.29 \\
\hline Cassava leaf & 2.46 & ND & 4.65 & 20.23 & 0.79 & 5.99 & 2.77 & ND & 2.89 & 1.10 & ND & ND & ND \\
\hline
\end{tabular}

Mangifera indica L. (Mango), Parkia biglobosa (Ugba), Proposis africanus (Okpeyi), Anacardium occidentale (Cashew)

and Manihot esculenta (Cassava)

ND: Not Detected. 


\section{DISCUSSION}

The Ti concentration in cashew stem of overburden and Okpeyi stem of control soil are quite high. These plant parts may be used as hyper accumulators for $\mathrm{Ti}$ detoxification from polluted soils. This effective xylem loading may be due to smaller sequestration of metals in the root vacuoles of the plants (Lasat et al., 1998). The distribution of $\mathrm{Cr}$ in a contaminated soil may not necessarily be uniform, and in most agricultural soils the highest concentrations are usually found near the soil surface (Robinson et al., 2003). This may partly be responsible for the variations in the distribution of $\mathrm{Cr}$ in plants grown on mine overburden and control soil. The observed values in okpeyi and cashew plants in the control soil exceed maximum permissible limits in plants $(1300 \mu \mathrm{g} / \mathrm{kg}$ ) (ATSDR, 1989).

Manganese sorption in the plants grown on mine overburden and control soils showed a range of $5.81-67.27 \mathrm{mg} / \mathrm{kg}$ for mine overburden and 4.19 - $54.95 \mathrm{mg} / \mathrm{kg}$ control soil. Okpeyi leaf in both soils showed a high values at $44.18 \mathrm{mg} / \mathrm{kg}$ and $54.95 \mathrm{mg} / \mathrm{kg}$ for overburden and control soil respectively. Thus okpeyi leaf can be a good source of hyper accumulator for Mn detoxification in soil (Baker, 1981). Mango stem and leaf grown on mine overburden also showed elevated levels of $\mathrm{Mn}$ with concentrations of $27.82 \mathrm{mg} / \mathrm{kg}$ and $67.27 \mathrm{mg} / \mathrm{kg}$ respectively, while that of control soil have values of 6.59 $\mathrm{mg} / \mathrm{kg}$ and $23.64 \mathrm{mg} / \mathrm{kg}$ respectively for stem and leaf. Thus mango can act as a hyper accumulator for Mn removal for contaminated soil. Mn accumulation in humans above the provisional guideline value of $0.3 \mathrm{mg} / \mathrm{K}$ will lead to apparent ill effects (WHO, 1981). Another possible reason for the high $\mathrm{Mn}$ concentration observed may be attributed to the fact that affinity of trace elements for Mn oxide was usually much greater than $\mathrm{Fe}$ and Al oxides (Violante et al., 2010).
Expectedly, soil organic matter and clay soils have been identified as having the capacity to contain $\mathrm{Fe}$, therefore the higher Fe concentration observed in the control plant more than the plants grown on mine overburden soil may be as a result of the above factor. These are made possible through the formation of $\mathrm{Fe}$ - complexes. Okpeyi leaf and stem in control soil were observed to contain the highest amount of $\mathrm{Fe}$ in their stem and leaf - $101.50 \mathrm{mg} / \mathrm{kg}$ (stem) and 71.40 $\mathrm{mg} / \mathrm{kg}$ (leaf). The maximum permissible limit for $\mathrm{Fe}$ in foods is $1 \mathrm{mg} / \mathrm{kg}$; therefore the values of $\mathrm{Fe}$ obtained from the above plants are quite higher than the World Health Organization limit (WHO, 1983). The uptake of $\mathrm{Ni}$ is carried out mainly by root systems via passive diffusion and active transport (Seregin and Koznevnikova, 2006). This may partly be responsible for the observed concentrations in all the plant samples studied. It has been observed that $\mathrm{Cu}^{2+}$ and $\mathrm{Zn}^{2+}$ inhibit $\mathrm{Ni}^{2+}$ uptake competitively, these three soluble metal ions seem to be absorbed by the same transport system (Körner et al., 1987). In addition, soluble Ni compounds could also be absorbed via the $\mathrm{Mg}$ ion transport system, because of the similar charge/size ratio of the two metal ions (Oller et al., 1997). Maximum permissible limit of $\mathrm{Ni}$ in foods is $5 \mu \mathrm{g} / \mathrm{kg}$ body weight (WHO, 1991).

Since soils are often contaminated with various metals such as $\mathrm{Cu}$ (McGrath et al., 2001), it is not surprising that the observed concentrations of $\mathrm{Cu}$ are at elevated levels in both sampled soil plants. Another factor which may be responsible for the $\mathrm{Cu}$ detected may be due to the presence of $\mathrm{Zn}$ and $\mathrm{Fe}$ in the samples (Chaney, 1988). The low pH of control soil due to the presence of humus substance may also have contributed to the higher $\mathrm{Cu}$ content in the control soil plant than in the overburden plants. The presence of Re in both plants may be attributed to the 
presence of the metal in the soil, since most heavy metals are present in the soil. Interestingly, Okpeyi and cashew plants showed a similar pattern of metal biosorption in all the metals studied. These two plants can be good candidates for bioremediation of contaminated soils.

The low values of $\mathrm{Zn}$ uptake may be ascribed to low uptake across the plasma membrane, sequestration in a subcellular organelle and precipitation as insoluble salts (Lasat et al., 1996). In slightly, basic anoxic marsh sediment environments, $\mathrm{Zn}$ is effectively immobilized and not bioavailable (Gambrell et al., 1991). Very high abundances of soluble $\mathrm{Zn}$ are present under well oxidized conditions at $\mathrm{pH} 5$ to 6.5 , whereas low abundances of soluble $\mathrm{Zn}$ are present at $\mathrm{pH} 8$ under all redox conditions and at $\mathrm{pH} 5$ to 6.5 under moderately and strongly reducing conditions (Gambrell et al., 1991). In polluted environments, most $\mathrm{Zn}$ is scavenged by nondetrital carbonate minerals, organic matter and oxide minerals and is less mobile than $\mathrm{Cd}$ and $\mathrm{Pb}$ (Prusty et al., 1994). Okpeyi plant grown in overburden soil has $\mathrm{Zn}$ concentrations 3.69 $\mathrm{mg} / \mathrm{kg}$ (stem) and $2.49 \mathrm{mg} / \mathrm{kg}$ (leaf). Cassava concentration in the same soil is $1.52 \mathrm{mg} / \mathrm{kg}$ (stem) and $1.88 \mathrm{mg} / \mathrm{kg}$ (leaf). In plants grown on control soil Okpeyi showed $\mathrm{Zn}$ concentrations of $0.0 \mathrm{mg} / \mathrm{kg}$ (stem) and 2.33 $\mathrm{mg} / \mathrm{kg}$ (leaf), while cassava values of $\mathrm{Zn}$ are $49.08 \mathrm{mg} / \mathrm{kg}$ (stem) and $2.89 \mathrm{mg} / \mathrm{kg}$ (leaf).

Strontium was detected in plants grown in overburden and control soils. However, all the plants grown in overburden soil show considerable quantities of $\mathrm{Sr}$ with a range of $0.69-3.55 \mathrm{mg} / \mathrm{kg}$. The observed concentrations in control soil plants are 1.10 $5.08 \mathrm{mg} / \mathrm{kg}$. The observed concentration of $\mathrm{Ru}$ in the plants grown on control soil are quite significant with Okpeyi plant having the highest concentration of $210.24 \mathrm{mg} / \mathrm{kg}$ (stem) and $159.39 \mathrm{mg} / \mathrm{kg}$ (leaf); followed by cashew plant with observed concentrations of 143.45 $\mathrm{mg} / \mathrm{kg}$ (stem) and $121.44 \mathrm{mg} / \mathrm{kg}$ (leaf). This trend is similar to trends where Okpeyi and cashew plants showed high tendency to biosorb more of the metals studied. Being in the region of a coal belt, this is also an indication that the soil is rich in Ru. Ythium and barium were detected in small amounts in plants grown on both soils. Ugba plant showed high tendency to absorb $\mathrm{Y}$ and $\mathrm{Ba}$ from overburden soil with observed concentrations of $1.34 \mathrm{mg} / \mathrm{kg}$ (stem, Y), 1.97 $\mathrm{mg} / \mathrm{kg}$ (leaf, Y), $7.07 \mathrm{mg} / \mathrm{kg}$ (stem, Ba) and $15.22 \mathrm{mg} / \mathrm{kg}$ (leaf, Ba). This trend was also observed for control plant where ugba plant has the highest absorption of $\mathrm{Ba}$ with concentrations of $7.52 \mathrm{mg} / \mathrm{kg}$ (stem) and 4.48 $\mathrm{mg} / \mathrm{kg}$ (leaf).

\section{Conclusion}

Bioavailability of metals in some selected plants grown on mine overburden and control soil farmlands have been shown to contain considerable quantity of the metals studied. The results also indicate that Okpeyi and cashew show a similarity in the biosorption of the metals. This however is an indication that the two plants can be good candidates for soil remediation. Metals like $\mathrm{Ti}$ and $\mathrm{Mn}$ were higher in concentration from plants grown in overburden that the plants from control soil. The mining activities contributed significantly to the low levels of metals observed in the overburden plants than from control soil plants. This partly was attributed to the fact that most trace metals mobility occurred at undisturbed surfaces, thereby increasing the rate of biosorption in plants. This however was not the case in plants grown on overburden soil.

\section{REFERENCES}

ATSDR (Agency for Toxic Substances and Disease Registry). 1989. Toxicological 
Profile for Chromium. US Public Health Service, (ATSDR/TP88/10). Washington, DC,

Baker AJM. 1981. Accumulators and excluders strategies in the response of plants to heavy metals. J. Plant. Nutrn., 3:643-654.

Begonia MT, Begonia GB, Ighoavodha M, Gilliard D. 2005. Lead accumulation by Tall Fescue (Festuca arundinacea Schreb.) grown on a lead-contaminated soil. Int. J. Environ. Res. Public Health, 2(2): 228-233.

Bernal MP, McGrath SP. 1994. Effects of pH and heavy metal concentrations in solution culture on the proton release, growth and elemental composition of Alyssum murale and Raphanus sativus L. Plant Soil, 166: 83-92.

Bural GI, Dion DG, Glick BR. 2000. Plant growth-promoting bacteria that decrease heavy metal toxicity in plants. Can. J. Microbiol., 46: 237-245.

Chaney RL. 1988. Metal speciation and interactions among elements affect trace element transfer in agricultural and environmental food-chains. In Metal Speciation: Theory, Analysis and Applications, Kramer JR, Allen HE (eds). Lewis Publishers: Chelsea MI; 218-260.

Crowley DE, Wang YC, Reid CPP, Szansiszla PJ. 1991. Mechanisms of iron acquisition from siderophores by microorganisms and plants. Plant Soil, 130: 179-198.

Ernst WHO. 1996. Bioavailabilty of heavy metals and decontamination of soil by plant. Appl. Geochem., 11: 163-167.

Ganbrell RP, Wiesepape JB, Patrick WH. Jr, Duff MC. 1991. The effects of $\mathrm{pH}$, redox, and salinity on metal release from contaminated sediment. Water Air Pollution, 57-58: 359-367.

Hart JJ, Welch RM, Norvell WA, Sullivan LA, Korchian LV. 1998. Characterization of cadmium binding, uptake and translocation in intact seedlings of bread and durum wheat cultivars. Plant Physiol., 116: 1413-1420.

Joint FAO/WHO Expert Committee on Food Additives. 1983. Toxicological Evaluation of Certain Food Additives and Food Contaminants. Cambridge University Press: Cambridge.

Korner IE, Moller IM, Jensen P. 1987. Effects of $\mathrm{Ca}^{2+}$ and other divalent cations on uptake of $\mathrm{Ni}^{2+}$ by excised barley roots. Plant Physiol., 71: 49-54.

Kupper H, Kroneck PMH. 2007. Metal Ions in Life Sciences (vol 2), Sigel A, Sigel H, Sigel RKO (eds). John Wiley and Sons: Chichester, UK; 31-62.

Lasat MM. 2002. Phytoextraction of toxic metals: A Review of Biological Mechanisms. J. Environ. Qual., 31: 109120.

Lasat MM, Baker AJM, Kochian LV. 1998. Altered zinc compartmentation in the root symplasm and stimulated $\mathrm{Zn}^{2+}$ absorption into the leaf as mechanisms involved in $\mathrm{Zn}$ hyperaccumulation in Thlaspi caerulescens. Plant Physiol., 118: 875883.

Lasat MM, Baker AJM, Korchian LV. 1996. Physiological characterization of root $\mathrm{Zn}^{2+}$ absorption and translocation to shoots in Zn hyperaccumulator and nonaccumulator species of Thlaspi. Plant Physiol., 112: 1715-1722.

Mcgrath SP, Zhao FJ, Lombi E. 2001. Plant and rhizosphere processes involved in phytoremediation of metal-contaminated soils. Plant Soil, 232: 207-214.

Oller AR, Costa M, Oberdörster G. 1997. Carcinogenicity assessment of selected nickel compounds. Toxicol. Appl. Pharmacol., 143: 152-166.

Pitchell J, Kuroiwa K, Sawyer HT. 1999. Distribution of $\mathrm{Pb}, \mathrm{Cd}$ and $\mathrm{Ba}$ in soils and 
plants of two contaminated soils. Environ. Pollut., 110: 171-178.

Prusty BG, Sahu KC, Godgul G. 1994. Metal contamination due to mining and milling activities at the Zawar zinc mine, Rajasthan, India. I. Contamination of Stream Sediments: Chemical Geology, 112: 275-292.

Robert BK. 1992. Standard Operating Procedure for EPA's LBL Energy Dispersive X-Ray Fluorescence Spectrometry

Robinson B, Fernandez JE, Madejon P, Maranon T, Murillo JM, Green S, Clothier B. 2003. Phytoextraction; an assessment of biogeochemical and economic viability. Plant Soil, 249: 117125.

Romheld V, Marschner H. 1986. Mobilization of iron in the rhizosphere of different plant species. Adv. Plant Nutri., 2: 155204.
Salt DE, Blaylock M, Kumar PBAN, Dushenkov V, Ensley BD, Chet I, Raskin I. 1995. Phytoremediation: A novel strategy for the removal of toxic metals from the environment using plants. Biotechnol., 13: 468-475.

Seregin IV, Kozhevinikova AD. 2006. Physiological role of nickel and its toxic effects on higher plants. Russ. J. Plant Physiol., 53: 257-277.

Thangavel P, Subbhuraam CV. 2004. Phytoextraction: Role of hyperaccumulators in metal contaminated soils. Proc. Indian Natn. Sci. Acad., B70 (1): 109-130.

Violante A, Cozzolino V, Perelomov L, Caporale AG, Pigna M. 2010. Mobility and bioavailability of heavy metals and metalloids in soil environments. J. Soil Sci. Plant Nutr., 10(3): 268-292. 